\title{
Making sense of the COVID-19 pandemic from the Bible - Some perspectives
}

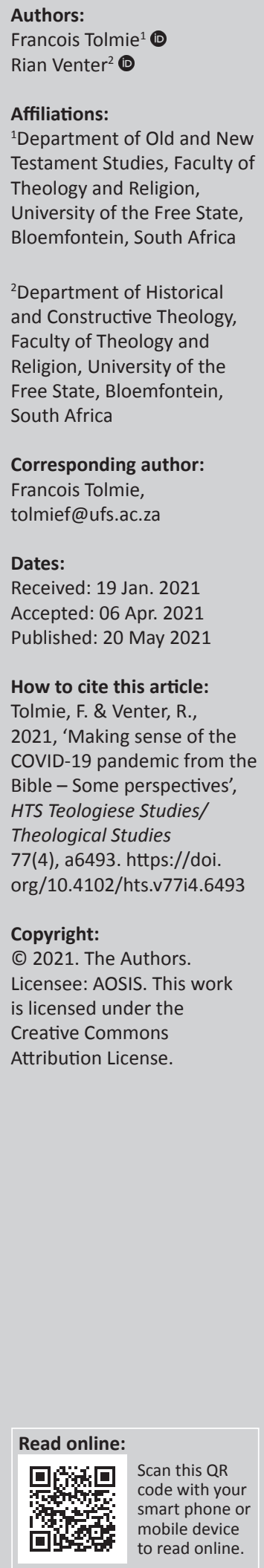

In this article, a brief survey of some of the ways in which biblical scholars try to make sense of the coronavirus disease 2019 (COVID-19) pandemic is offered. The views of the following scholars are discussed: Walter Brueggemann, Ying Zhang, John Goldingay and Kathleen Scott Goldingay, N.T. Wright, Philemon M. Chamburuka and Ishanesu S. Gusha, and Peter Lampe. This is followed by the reflections of a biblical scholar and a systematic theologian. From the perspective of a biblical scholar, the following issues are raised: the richness of biblical traditions, the influence of social location on the interpretation of the pandemic in the light of the Bible, the importance of the emphasis on lament, the reluctance to interpret the pandemic as a punishment from God, the importance of the interpreter's view of God and the emphasis on the way in which the 'new normal' should be approached. From the perspective of a systematic theologian the following issues are discussed: The nature of doing theology, the role of the symbol of the Divine, performativity of sense-making, the Trinitarian confession, an emerging new self and the importance of an ethic of responsibility.

Contribution: The article is a response to the COVID-19 pandemic and emphasises the critical importance of engaging the Christian scripture. The role accorded to hermeneutics and to an explicit interdisciplinary conversation makes a particular contribution to the emerging crisis discourse.

Keywords: COVID-19; pandemic; Bible; hermeneutics; Old Testament studies; New Testament studies; systematic theology; ethics; new normal; pandemic as punishment from God.

\section{Introduction}

As usually happens in times of crisis, millions of people all over the world turned to religion for guidance and spiritual comfort during the pandemic. Studies focussing on the roles that religion and specifically the Bible play in people's reactions to the virus have already begun to appear, with some interesting findings, as the following show: In a study published in June 2020, Bentzen (2020) notes that daily data on Google searches for 95 countries indicated that in May of that year, searches for the keyword 'prayer' increased to the highest levels ever (for all levels of income); Isiko (2020:83-84) finds that in Uganda, both Christianity and Islam use the notions of eschatology and apocalypse to explain the pandemic; and Vermeer and Kregting (2020:1-12) point out that in the Netherlands, the levels of people diagnosed with the coronavirus disease 2019 (COVID-19) were significantly higher in the 'Dutch Bible belt' and in the southern, traditionally Catholic provinces than in the rest of the country. In an investigation of sermons preached in some congregations of the Dutch Reformed Church in South Africa on 22 and 29 March 2020, Steyn, Wepener and Pieterse (2020:1-20) found that preachers typically focussed on inviting congregants 'to see, with the help of faith and discernment, God's divinity as a comfort and hope, and to be serviceable'. In a further study along these lines, Steyn and Wepener (in press) point out the language of God found in these sermons: 'God is present and near. God is powerful. God is conqueror over death. God breathes life and creates. God('s love) is stronger than death. God is in control'.

Against this broader background, this study focusses specifically on the way in which biblical scholars try to make sense of the pandemic. For this purpose, six studies by biblical scholars were selected; they are summarised briefly with a focus on the dominant notions characterising each particular study. This is followed by the reflections of a New Testament scholar and a systematic theologian. We trust that this study will contribute to further deliberation on this very important topic.

Note: Special Collection: From timely exegesis to contemporary ecclesiology: Relevant hermeneutics and provocative embodiment of faith in a Corona-defined world - Festschrift for Stephan Joubert, sub-edited by Willem Oliver (University of South Africa) 


\section{Perspectives of biblical scholars Walter Brueggemann}

The book that Brueggemann (Columbia Theological Seminary, retired) published on the issue is titled Virus as a summons to faith. Biblical reflections in a time of loss, grief and uncertainty. In the first chapter, this well-known Old Testament scholar distinguishes three ways in which plagues are interpreted in the Old Testament. He calls the first option 'the transactional mode of covenant', meaning that God rewards obedience and punishes disobedience. According to such a view, plagues are a form of divine punishment against those violating the covenantal order (Brueggemann 2020:2-5). The second option is described as 'YHWH's purposeful enactment of force' and refers to instances where YHWH uses force to achieve a specific purpose, as happens in the case of the plagues in the Exodus narrative (Brueggemann 2020:5-10). Brueggemann summarises the third option as 'YHWH's holiness enacted in freedom'. This refers to the fact that God can sometimes act in 'utter freedom without reason, explanation or accountability, seemingly beyond any purpose at all' (Brueggemann 2020:10). He refers to the Book of Job as an example of such a view. Brueggemann believes that one can interpret the COVID-19 crisis in terms of any one of these three options, but it seems as if he opts for the third one, that of pausing 'before God's raw holiness in a world that is not tamed by our best knowledge' (Brueggemann 2020:18; his emphasis).

In the second chapter, Brueggemann discusses 2 Samuel 24:1-25, according to which David chooses three days of pestilence as punishment, not because the time of suffering is shorter than that of the other two options that he is given, but because the pestilence comes directly from $\mathrm{YHWH}$ and he is aware how great YHWH's mercy is. Although Brueggemann does not think that one should transfer this idea directly to the pandemic, he does point out that it helps us to dare to imagine that the final word in such a crisis is not pestilence, but mercy (Brueggemann 2020:21-26).

In the next chapter, the focus falls on the Book of Jeremiah, in particular on the fact that the prophet took note that weddings were cancelled because of the crisis that the people were experiencing. However, Jeremiah also envisioned a time when weddings would be resumed. Thus, God did not abandon his people or the world, but remained faithful. Brueggemann appropriates this as follows: in our time, the church may thus bring hope, based on God's faithfulness; she should witness to God's enduring hesed, even amid the pandemic (Brueggemann 2020:28-32).

Chapter 4 is devoted to the prayer of Solomon (1 Ki 8:23-53, 2 Chr 6:14-42). Brueggemann (2020:35-45) points out that disasters as such do not receive much attention in this prayer; the emphasis is rather on the notion of being faithful in praying and being ready to trust that YHWH will hear one's prayers. Appropriated in terms of the current context, this means that the 'Virus is thereby robbed of its capacity to disorder daily life. In effect these texts decisively change the subject from disaster to the rule of $\mathrm{YHWH}^{\prime}$ (Brueggemann 2020:43; his emphasis).

In the next chapter, Brueggemann (2020:46-56) interprets Psalm 77 as indicative of a move from a preoccupation with the self to submission to and dependence on God, an idea that is appropriated for our times as the notion that we have to 'move between a petty religion of calculating obedience aimed at well-being and a fully-liberated, imaginative religion of awe and amazement and trembling before the Holy One' (Brueggemann 2020:55).

Brueggemann (2020:57) begins Chapter 6 by noting that one can trust in God in such a crisis without necessarily regarding God as the cause of it. More importantly, the crisis confronts us with the 'indifferent, exploitative world of global selfsufficiency' (Brueggemann 2020:57) that we live in and that all of us enjoy so much. Thus, as happens in Isaiah 43:18-19, we may think of God as doing something new amongst us so that we can imagine a new normal which God gives us graciously (Brueggemann 2020:59).

In the final chapter, Brueggemann (2020:61-64) begins by noting Paul's statement that all creation is groaning ( $\mathrm{Rm} 8: 22)$ and expounds Isaiah 42:14-15 as showing that newness never comes easily; it is a painful process causing much anguish and groaning, a crying out. He moves on to a discussion of four texts expressing the same notion of anguished groaning as Romans 8 (Gn 4:10, Ex 2:23, Job 31:38-40 and Lk 19:39-40) and argues that the future is never an easy gift. 'It is rather a mystery-shrouded gift of God that all creatures are invited to receive in deep cost' (Brueggemann 2020:65). Believers should thus not try to avoid groaning or even attempt to opt for a type of groaning precluding newness. What is needed is a form of groaning that breaks current despair and hopes for newness, as happened in the exile (Is 65:17-25) and at the cross of Jesus (Ps 22:1) (Brueggemann 2020:68-69).

In his book, Brueggemann thus offers a variety of hermeneutical options for making sense of the current COVID-19 crisis. For our purposes, the dominating key notions may be summarised as punishment, purposeful force from YHWH's side, awe before $\mathrm{YHWH}^{\prime}$ 's holiness, YHWH's hesed, YHWH's rule, new things being done by $\mathrm{YHWH}$, anguished groaning, the extinction of despair and hope for God's newness.

\section{Ying Zhang}

As the title of the article ('Reading the Book of Job in the pandemic') by Zhang (East India Normal University, Shanghai) indicates, this study focusses specifically on the Book of Job. Zhang (2020:607-610) argues that the book offers three perspectives on Job: Job the sufferer (losing his children, property and health), Job the mourner (defending his innocence, emotionally mourning about his terrible misery and insistently protesting his blamelessness) and Job the protester (trying to vindicate himself, putting God on trial 
as his adversary). Zang concedes that it might be difficult to show the relevance of this unique portrayal of Job to 'other experiences of injustice, inequality, and undeserved suffering' (Zhang 2020:610), but she notes that the way in which Job challenges God's justice, and, in particular, the question that is raised in Job 21:7 ('Why do the wicked live on, reach old age and grow mighty in power?') is relevant, as it raises the issue of divine justice, as well as moral order.

In the last part of the article, Zhang turns to the pandemic in the light of Job's existential suffering. She raises two issues. Firstly, Zhang (2020) draws attention to the way in which people hurt Job by their aloofness as a result of his health problem, and this is appropriated as follows:

The same feelings of being loathed and discriminated against have been experienced by many who were healthy yet had geographical, ethnic, or other connections to the place of the coronavirus outbreak ... [I]t is certainly not right to be biased against those who are simply Wuhanian, or Chinese, or Asian. (p. 611)

Secondly, she draws attention to a young Chinese woman who reported daily on social media on her struggle with COVID-19. Unlike Job, she never complained. She finally recovered. The way in which this woman reacted reminded Zhang (2020) of a remark by Maimonides, an important medieval Jewish scholar, who noted that Job lacked true knowledge of God, in particular:

$[T]$ hat God watches over natural phenomena and diverse species rather than individual beings ... In other words, what God takes care of is only the natural order, and in this sense, divine providence can be only general, not particular, providence. (pp. 611-612)

Thus, Zhang appropriates the Book of Job in terms of two key notions, namely discrimination (against Chinese people) as a result of the virus and the way in which the notion of God's providence is to be understood.

\section{John Goldingay and Kathleen Scott Goldingay}

The contribution by John Goldingay and Kathleen Scott Goldingay (both retired, living in Oxford, UK) is titled 'Thinking with the Old Testament about the pandemic'. They investigate stories about famine and epidemics in the Books of Genesis, Ruth, Samuel-Kings and Chronicles. They begin with some general remarks: Quite often God is depicted as the One who brings epidemics, but this is not always the case; sometimes epidemics just happen. When God is indicated as the subject, it might be a form of chastisement, but many Old Testament stories (such as the Book of Job) show that one cannot assume that such events are necessarily God's response to sin. The version of Solomon's prayer in Chronicles confirms this because God is asked to deal with every person in terms of the state of their hearts (2 Chr 6:2-30), which suggests that some people might need to be pardoned, whereas others might only need deliverance (Goldingay \& Scott Goldingay 2020:191-192).
Next, several Old Testament stories about epidemics are treated. The famine in Genesis 12 (the setting of the story being when Pharaoh takes Sarah into his harem) is not linked to God; it just happens. However, later it is God who strikes Pharaoh with an epidemic, meant to keep him from doing wrong. The seven-year famine mentioned in Genesis $41-47$ is not linked to God; neither is it depicted as divine punishment. Likewise, Joseph does not view his being sold into slavery as caused by his brothers' sin, but rather as something caused by God so that he would be in Egypt at the right time so that God could show compassion. The same is true of the famine mentioned in the Book of Ruth; without it, Ruth would not have met Naomi and Boaz and would not have found YHWH. In Exodus 6-12, the series of disasters comes from YHWH, and is depicted as an attempt to convince Pharaoh to let Israel leave, but he does not heed it. The authors also note that most of the famines and epidemics that are meant as divine chastisement are aimed at Israel, as happens in 2 Samuel 21 (a three-year famine caused by Saul's treatment of the Gibeonites). In 1 Samuel 5, God strikes the Philistines with tumours, because they took the covenant chest. Furthermore, the events narrated in 2 Samuel 24 and 1 Chronicles (in different ways) are highlighted. In this case, David chooses the epidemic coming from God because he instinctively places his trust in YHWH's merciful nature (Goldingay \& Scott Goldingay 2020:192-197).

The Old Testament perspectives are appropriated in different ways. In the case of the Book of Ruth, the fact that the epidemic is part of a bigger story is highlighted (Goldingay \& Scott Goldingay 2020):

[O]ur epidemic is not a beginning, and nor (please God) will it be an end, but is part of an ongoing story. If epidemic issues from our stupidity, this fact does not mean that God abandons us or declines to weave it into his story. (p. 195)

At the end of the article, John Goldingay points out that the Old Testament offers various perspectives on issues, and that they are instructive in diverse ways. In this case, he was puzzled by the fact that the rules in the Torah do not refer to dealing with famine and epidemic, from which he deduces that we should not look for explanations of the epidemic, but rather that we should reflect on it and repent, as Jesus asked people to do after the incident with the tower of Siloam. Furthermore, Leviticus 19:13-18 specifically requires of believers to express their love for their neighbours concretely under these circumstances. Finally, he also draws attention to the Psalms that model a type of crying unto God that is appropriate during an epidemic such as ours, whereas the Books of Proverbs, Job and Ecclesiastes indicate the need to think about the revolutionising implications of the pandemic for the future (Goldingay \& Scott Goldingay 2020:196-197).

In this case, the key notions in appropriating insights from the Old Testament for the current COVID-19 crisis may be summarised in terms of an ongoing story of repentance and neighbourly love. 


\section{N.T. Wright}

In his God and the pandemic. A Christian reflection on the coronavirus and its aftermath, Wright (Oxford) begins by pointing out that the best way to react to the virus is not to ask 'Why?', but 'What can we do?' He rejects what he calls 'knee-jerk reactions', such as conspiracy theories, blaming other people, apocalyptic interpretations or viewing the pandemic as God's punishment because of people's lifestyles (Wright 2020:1-7). Turning to the Old Testament, he points out that it is true that the prophets interpreted the great disaster of the Babylonian exile as punishment for the sins of Israel. Furthermore, in some of the Psalms (e.g. 1 and 37), the link between sin and ill fortune is confirmed. Nevertheless, there is also another view, as can be seen in Psalms 73 and 44, according to which a link between good behaviour and good fortune is denied. The Book of Job, in particular, challenges the idea that God is using the coronavirus to call people to repentance. In fact, this book shows that there are two stories in the Old Testament: the story of the covenant between God and Israel, but also another story of a dark power that is always trying to destroy God's good work (Wright 2020:8-15). Wright (2020) confesses that he does not know how to explain this dark power:

[W] e are simply to know that when we are caught up in awful circumstances, apparent gross injustices, terrible plagues - or when we are accused of wicked things of which we are innocent, suffering strange sicknesses with no apparent reason, let alone cure - at those points we are to lament, we are to complain, we are to state the case and leave it with God. (p. 14)

Next, Wright moves to Jesus and the Gospels. He not only concedes that Jesus occasionally warns people to repent in the light of disasters (e.g. in Lk 13:1-9), but he also points out that he does not do so consistently (John 9). More importantly, one should realise that Jesus himself was the ultimate sign; the Jesus-events constituted the decisive call to repentance, because they are linked to the coming of the Kingdom. Furthermore, Wright argues that the notions of the Kingdom, control and sovereignty should be rethought in the light of Jesus' death on the cross. John 11 helps us in this regard; Jesus does not link Lazarus' death to sin, but rather weeps and then commands Lazarus to come out of the tomb (Wright 2020:15-29). In the rest of the New Testament, Wright finds a similar picture: people are called to repentance because of God's Kingdom and not because of famines or plagues. According to Wright, the most important passage for making sense of the coronavirus is Romans 8. This chapter calls on believers to pray when the world is experiencing pain; even though we do not know what to pray for, when we pray, this becomes the moment when we become part of the inner triune existence of God, the God whom we see in Jesus as the God weeping at the tomb of Lazarus (Wright 2020:30-51).

In the final chapter, Wright draws everything together. The appropriate initial response to the pandemic is lament. Furthermore, we should reconsider the way we talk about God's 'control' of the world. It is not something operating mechanically; in fact, evil intrudes into God's plan, and, because God delegated many things to humankind, God is sometimes shocked by some of the things that happen. Finally, Wright turns to the church's task. The church is called to produce signs of the Kingdom, namely by actions speaking of the new creation. Wright also points out the danger of just moving back into our old ways after the pandemic; therefore, the time of lament should also become a time of prayer and hope for new policies that would heal the world (Wright 2020:52-77).

The key notions in Wright's approach may be summarised as lament, evil as intruder in God's creation, prayer and hope.

\section{Philemon M. Chamburuka and Ishanesu S. Gusha}

As the title of their article 'An exegesis of the parable of the Good Samaritan (Lk 10:25-35) and its relevance to the challenges caused by COVID-19' indicates, Chamburuka and Gusha (both from the University of Zimbabwe) take a specific parable of Jesus as point of departure. After a thorough historical, contextual, formal and detailed analysis, they offer a description of the impact of COVID-19, as well as of the social, economic and political effects of the pandemic (Chamburuka \& Gusha 2020:1-5). In the light of this discussion, they identify the following challenges posed by the COVID-19 crisis: 'discrimination (ethnicity, racism and regionalism), hate speech, social stigma, xenophobia and stereotypes' (Chamburuka \& Gusha 2020:5). Against this background, three issues then become important. Firstly, the parable encourages us to refrain from discrimination, for example, by referring to the virus as an Asian or Chinese virus or as the Wuhan virus, by suggesting that Africans may be used as guinea pigs for anti-COVID-19 drugs, or by claiming that African migrants brought the virus to Italy. Secondly, the parable calls for compassion towards those in need. This means that those who are wealthy should offer financial assistance; practically, this means that countries such as the USA should not withdraw their financial support from the World Health Organization. At the same time, those who are poor should not celebrate the demise of those affected by COVID-19 - as Zimbabwe's defence minister did when she claimed that the virus was God's punishment on the USA. Thirdly, the parable teaches us that one's enemy is actually one's neighbour. In fact, the pandemic is showing us that we can never be self-sufficient; the entire world is in a position of need and this means that everybody is potentially a neighbour (Chamburuka \& Gusha 2020:6-7).

\section{Peter Lampe}

The contribution of Lampe (the University of Heidelberg, retired), titled 'Health and politics in the COVID-19 crisis from a New Testament hermeneutical perspective', considers the issue of alternative modes of living after the pandemic. Lampe begins by pointing out that the COVID-19 crisis has brought to light many pre-existing problems such as inequality, consumer behaviour, sexism and racism, and then 
takes Mark 3:1-6 (the healing of the man with a withered hand) as the starting point for suggestions from the New Testament with regard to alternative modes of living. In a first step, he points out that the story begins with conflict because it happens on a Sabbath. However, Jesus focusses on the pain (Lampe 2020):

$[T]$ here is no denying, no downplaying, no labelling of medical data as fake news ... Taking the problem seriously, looking the pain in the face, is the first step toward healing. (p. 118)

Next, Lampe moves to the issue of health and the law: Jesus brings the law to its true potential, that is giving rest. He thus shows that the law should be applied in a kind and humane way; practically, this means that people cannot insist on their rights, yet in the process sacrifice the health of others, as happened in Berlin in August 2020 when 20000 demonstrators gathered without masks and any social distancing (Lampe 2020:118-119).

Thirdly, Lampe points out the political dimension of the story. It alludes in a condemnatory way to some of the brutal military events in the Jewish War, and, like the story in Mark 8:22-26, it portrays Jesus as the true healer in contrast to Emperor Vespasian about whom similar healing stories were told. This critical attitude towards the powers of the time is also found elsewhere in Mark, thus offering an alternative perspective according to which only God and Jesus as God's Son are to be referred to in religious terms (Lampe 2020:119-120).

Finally, Lampe draws everything together: the COVID-19 crisis should serve as a 'trigger to reorientation'. The first step is to look the problem in the eye, and then to consider alternative approaches, such as avoiding apotheosising immanent things or principles such as profit at all cost, instead making humanity and kindness the basis of all actions and all law-making and realising that the insistence on monotheism enables us to stop absolutising immanent matters. Furthermore, for Christians, recovering from COVID-19 serves as a foretaste of the ultimate eschaton of which they hope (Lampe 2020:119-123).

The key notions in Lampe's approach may be summarised as focussing on the reality of the issue, kindness in applying the law and a critical attitude to apotheosising immanent things.

\section{Reflection by a New Testament scholar}

From the perspective of a New Testament scholar, the following may be noted. Firstly, one is struck by the richness of biblical traditions and how many different notions are found in the source document of Christianity that may be made relevant for such a crisis. In the discussion above, the key notions playing a role in the way in which each scholar tried to make sense of the pandemic in terms of the Bible have been listed, and if they are all thrown together (somewhat unsystematically), the broad variety is conspicuous: punishment, force, holiness, mercy/compassion, rule/kingdom, lament, despair, hope, discrimination, neighbourly love, evil and prayer. It is also significant that all the authors discussed above opt for approaches in which a variety of aspects are combined, rather than focussing on a single notion. In this way, the complexity of making sense of the COVID-19 crisis is conveyed in an admirable manner.

Secondly, as is always the case when one interprets texts, the influence of the social location of interpreters on the way in which they appropriated the biblical texts is noticeable. Brueggemann speaks about the situation in the USA, and Wright and Goldingay and Scott Goldingay (primarily) about the situation in the UK, whilst Lampe has the situation in Germany in mind. That the notion of discrimination plays a major role only in the contributions of Zhang and Chamburuka and Gusha is clearly related to the fact that their appropriation of the Bible is influenced by particular experiences in the parts of the world in which they live, in particular Shanghai and Zimbabwe.

Thirdly, the emphasis on lament or groaning as a response to the pandemic is a significant contribution that needs to be heeded by other theologians, and, in particular, by pastors if the surveys by Steyn et al. (2020) mentioned in the first paragraph of this study is a true reflection of the somewhat narrow way in which pastors tend to preach on the pandemic. As we have seen, for Wright, lament is the appropriate initial response to the crisis situation, whereas the notion of the groaning of creation is an important aspect of Brueggemann's approach. In a more or less similar way, John Goldingay draws attention to Psalms modelling a type of crying unto God that is appropriate during such an epidemic. The way in which Job is depicted as a sufferer and mourner (Zhang) is also relevant here. The point is that the emphasis on lament as appropriate action shifts the focus from just providing easy answers - always a temptation for pastors and theologians! - to an admission of our helplessness and a lack of answers in explaining the pandemic.

Fourthly, it is noteworthy that a reluctance to interpret the pandemic as a punishment from God is clearly visible in the studies discussed above. Wright rejects such notions as a knee-jerk reaction and provides solid theological arguments for a different approach. Brueggemann identifies punishment as one of the three ways in which plagues are interpreted in the Old Testament (the so-called 'transactional mode of covenant'), but shies away from appropriating the pandemic in this way in the rest of his book. In fact, he explicitly notes further on that one may trust in God under such a crisis without necessarily regarding God as the cause of it, and warns against a type of religion based on calculating obedience. In a similar vein, Goldingay and Scott Goldingay not only argue that the Old Testament quite often depicts God as the One who brings epidemics, but also note that this is not always the case; sometimes epidemics just happen. Furthermore, Chamburuka and Gusha explicitly reject the 
notion of punishment as a way to interpret the pandemic. The reluctant and nuanced way in which scholars handle the notion of the pandemic as a punishment from God is to be lauded, as it serves as a much-needed corrective to the easy way in which this idea is sometimes thrown around in fundamentalist circles.

Fifthly - and closely related to the previous point - it is clear that one's view of God plays a very important and perhaps even a determinative role in the way in which one makes sense of the current situation. The choice not to view the COVID-19 crisis as punishment from God highlighted in the previous paragraph seems to be directly linked to the way in which God is perceived, since such a view is based on God being viewed foremost in terms of mercy instead of retribution. This idea occurs in every study in one way or other. For example, both Brueggemann and Goldingay and Scott Goldingay highlight the events in 2 Samuel 24, according to which David chooses the epidemic coming from God, as he instinctively places his trust in YHWH's mercy. Goldingay and Scott Goldingay also point out that God does not abandon us, even if the pandemic is a result of humanity's own stupidity. Wright's depiction of God may also be highlighted in this regard: the God whom we see in Jesus is the God weeping at the tomb of Lazarus.

Corresponding to such a view of God, there is also an emphasis on the importance of neighbourly love in most of the studies, that is God wants believers to act in a loving and kind way. This notion is especially prominent in the studies of Zhang and Chamburuka and Gusha, but is also emphasised by Goldingay and Scott Goldingay, Lampe and Wright.

There are two further notions with regard to the way in which God is perceived that should be pointed out, although they do not figure as prominently in the studies above as the notion of mercy. The first one is God's holiness. This aspect is stressed particularly by Brueggemann: 'YHWH's holiness enacted in freedom' as he refers to it, that is the fact that God sometimes acts in 'utter freedom without reason, explanation or accountability, seemingly beyond any purpose at all' (Brueggemann 2020:10). He also notes that our only adequate response in such a situation is to pause in awe before God's holiness. The other issue is God's providence/divine justice. Zhang puts this issue on the table and, based on an insight of Maimonides, opts for interpreting God's providence as only general and not particular providence. Wright touches upon a somewhat similar matter when he discusses God's control of the world and explicitly points out that it should not be regarded as something operating mechanically; it is rather a matter of evil intruding into God's plan. Furthermore, Wright notes that God delegated many things to humankind, and that God is sometimes even shocked by some of the things happening. This particular issue is not discussed by the other authors, but it is an idea needing more reflection.

Finally, all the scholars consider the 'new normal' after the pandemic. This is done in a variety of ways, but broadly speaking, the emphasis falls on the fact that things cannot continue as before. John Goldingay links this to the Books of Proverbs, Job and Ecclesiastes, calling upon us to think about the revolutionising implications of the pandemic for the future. Wright refers to the church's task of producing signs of the Kingdom, and, in particular, actions speaking of new creation. We should not move back to our old ways, and thus the time of lament should become a time of prayer for new policies that would heal the world. Brueggemann notes that the crisis confronts us with the exploitative ways in which we lived and the indifferent self-sufficiency characterising our existence, and that we should now imagine God as doing something new amongst us, a new normal given to us graciously by God. Lampe, especially, focusses on the COVID-19 crisis as a 'trigger to reorientation' and puts very important issues on our future agenda such as a choice against apotheosising immanent things or principles (e.g. profit at all cost), making humanity and kindness the basis of all actions, of all law-making and realising that the insistence on monotheism enables us to stop absolutising immanent matters. And, of course, there is the on-going problem of discrimination that is highlighted by Zhang and Chamburuka and Gusha. Thus, although this aspect is treated in different ways, the importance of a critical reflection on our old ways and the need for action receives its rightful place in studies investigated above.

\section{Reflection by a systematic theologian}

The invitation to suggest some perspectives from systematic theology underlines an important intuition - that intellectual engagement with a complex problem requires a multi- and inter-disciplinary effort. It has been an emerging realisation for a number of decades that the nature of challenges faced by contemporary society has become too layered to be addressed by only one discipline. It is commendable that leading Old and New Testament scholars like Brueggemann and Wright have addressed the COVID-19 condition from their respective disciplinary fields so swiftly. Whilst reading their reflections, however, one cannot escape the nagging feeling that something more is needed. The question is obviously: What could systematic theology contribute to? Webster's (2007) definition of the task of this discipline, that is:

$[A]$ ttempts a conceptual articulation of the Christian claims about God and everything else in relation to God, characterized by comprehensiveness and coherence. (p. 2)

It may point to the avenue which systematic theology may take. It is precisely the three elements of 'in relation to God', 'comprehensiveness' and 'coherence', which deserve attention. One encounters a glimpse of especially the last two in the early attempt by Thomas (2020) to offer a systematic theological contribution. In a typical 'loci approach', he addresses the pandemic under the rubrics of creation, providence, sin, anthropology, Christology, church, Spirit, hope and ethics. Although his treatment may appear as somewhat formally old-fashioned, materially he succeeds 
in discussing the pandemic theologically coherently and comprehensively, and also informed by more recent sensibilities in theology.

The focus of this article emphasises a second and crucial insight: making sense of the COVID-19 condition requires an appeal to Scripture as a normative source for doing theology. This evokes the old and difficult discourse of how the Bible is to be 'used'. The very nature of doing theology as hermeneutical crystallises with this, together with the corresponding dynamics of method and ultimately of imagination. It is interesting to examine how the biblical scholars executed their task. At a minimum, they looked for analogies, for example plagues and pestilence, and then they referred to divine causality, to the nature of creation, the scope of human practices and even the possibility of the dawn of something 'new'. The awareness of the plurality inherent in biblical texts is a cardinal contribution. This underscores the reservoir of meaning present, which can be explored in many diverse ways. These insights require some rhetorical moves beyond biblical studies, and this is where systematic theology may make a contribution. It should be stressed, however, that more than mere distilling or systematisation is at stake. The 'critical correlation' between an existential exigency and possible relevant biblical resources necessitates constructive theology. The distance between the 2020 pandemic and the ancient textual witnesses is vast; only by way of some form of imaginative construal could meaning result - or to employ typical hermeneutical idiom, could new possibilities for life be generated. Implicit and even hidden in the approaches of the Old and New Testament scholars are traces of 'paradigmatic' thinking, that is, reference to 'the overarching biblical story of creation, fall, redemption and consummation' (Hollinger 2002:169f.). The task of systematic theology as a constructive discipline should make that explicit.

This raises the question that has become increasingly pertinent: How does one theologise critical contemporary challenges? More and more one comes across theologies of emerging technologies, global warming and even of fashion! Before the COVID-19 pandemic, Gregersen and Henriksen (2017) advocated the development of 'theologies of tragedy and disaster' that would employ 'the symbolic resources of Christianity' to 'help people orient themselves in light of what happens' (Gregersen \& Henriksen 2017:331). To refer to texts that exhibit some form of analogy to current events would not amount to an adequate theology; a more penetrating wrestling with the core symbols of the Christian faith is required. At least three argumentative moves should take place. The crisis or challenge, in this case the COVID-19 pandemic, should be related to the central symbol of the Divine. An argument becomes 'theological' the moment the theos of the-ology starts to function as orientation. Secondly, the overarching narrative of the Bible - creation, brokenness, incarnation, renewal and consummation - provides a next layer for the creation of meaning. The Christian faith is in a sense dramatic. It tells a story which invites participation. A satisfactory theology of a pandemic cannot escape this trajectory. It may be exactly this that could establish the contribution of systematic theology to the conversation. Thirdly, sense-making entails more than a mere intellectual endeavour; it also has a performative function. The Christians' story does not only help to cope, but also encourages 'a way of life'. What Hadot (1995) has done for the scholarship of Greek philosophy applies equally to theology-understanding the world is accompanied by a way to live a good life. An adequate theology of the COVID-19 pandemic should intentionally and explicitly account for the new self that is created by the reference to the Divine and the script of the great drama. The self might be disrupted, comforted, healed and mobilised for greater civil responsibility. These three identified formal elements should obviously be explored in much greater depth, but the few suggestions may intimate the contours of the input by systematicians. Much has been written during the last few decades about a theological reading of the Bible. The three accents pointed out here might form the lenses for a theological hermeneutic for reading the Bible in a time of pandemic. It may generate a comprehensive and coherent reading whilst listening to the voice of the text.

The central place accorded to God in the theological discourse on COVID-19 should be explored in a bit more detail. In several of the biblical discussions, there is some reference to God. The perspectives by Brueggemann (2020) especially on 'YHWH's holiness enacted in freedom' (pp. 10-14) is particularly fruitful. What one misses, from a systematic theological view, is an explicit Trinitarian identification of the Divine. A Christian theologising of the pandemic should emphatically be done in the light of the being and act of the God who identified Godself as Father, Son and Spirit. This allows and encourages an immense scope of interpretative avenues. The Trinitarian Renaissance in theology over the past six decades is witness to the productive hermeneutical possibilities the Trinity as regulative optic could open. Smit (2009:66-69) talks about a 'Trinitarian spread', which this kind of theology opens. The three Persons of the Trinity are traditionally associated with creation, redemption and consummation. Put differently, when a Trinitarian hermeneutic is employed, one should think about the pandemic in ontological, cruciform and soteriological categories. One cannot avoid the fundamental question about the very nature of reality in the face of the existence of viruses. This is a major philosophical question (see e.g. the article by Pradeu, Kostyrka \& Dupré on virology 2016), which theology cannot escape. The antenna of the biblical scholars about the central applicability of Romans 8 is most applicable here. A multi-disciplinary conversation is, however, required here and is not a mere paraphrasing of biblical texts. The role of embodiment, vulnerability and suffering emerges intensely to the fore with the Jesus history. Furthermore, the Pentecost narratives warrant thinking in quantum categories - uncertainty, novelty and emergence. The sensibility by Brueggemann and Lampe about 'newness' and 'recovery' is most suggestive and fits finely into the 'turn to eschatology' in systematic theology. This could become a most fruitful intersection between biblical studies and 
systematic theology. The revolutionary and re-orientating possibilities of these categories as pointed out by these scholars re-affirm the realisation that eschatology has immense social transformative potential. The moment the Bible is read with theological, meaning Trinitarian, lenses, kaleidoscopic avenues are unlocked for making sense. This in no way advocates a return to dated attempts to find the doctrine of the Trinity in every Testament. At stake is a peculiar imagination that thinks creatively ontology, vulnerability, materiality and surprise together. In a startling way, a profile of the Divine emerges, which thinks causality, suffering and healing paradoxically in tandem. The pandemic cries out: Where is God? This cry for the presence of the transcendent has become the shape of the God-question of our time (see Duquoc 1992). A conventional theistic approach to God cannot really address this. The so-called 'omnimonster' cannot be credibly invited to the conversation. A Trinitarian imagining promises more resources for speaking in a way that is less embarrassing. For example, Trinitarian theology avoids domestication of the Divine and gives prominence to the notion of God's hiddenness. One finds this in all major Trinitarian scholars of the last few decades Barth, Jenson, Kasper, Jüngel and Tracy, to mention only a few. Trinitarian hiddenness is dialectical - the divine is absent and present, or better put: precisely present in absence and weakness. Great Christian thinkers from Paul to Luther and Bonhoeffer have encouraged us to perceive this. In a more elaborate conversation between biblical and systematic scholars, especially on the COVID-19 condition, this could be explored with mutually enriching effects.

Sense-making entails more than an intellectual explanation. In the discussions of the biblical scholars, one also sees the attention given to emotive responses. What is noteworthy is the space accorded by Wright to 'lament'. The subtitle of Williams's reflections - Candles in the dark (2020) - is instructive: Faith, hope and love in a time of pandemic. The Christian faith is a way of life that encompasses the full spectrum of human practices. Recently, the Scandinavian systematician Henriksen (2019) argued persuasively for understanding Christianity in terms of 'practices'. Systematic theology might prefer to move beyond pastoral therapeutics and to investigate what new self possibly emerges from the COVID-19 condition. More and more scholars have started to point out the formative function of doctrine. Doing systematic theology might happen elliptically in the field of the Divine-human encounter. The God we conceptualise will ultimately determine our anthropology. One might rephrase this: A Trinitarian faith will result in a Trinitarian self. What this entails might map the route to be taken for a fully fledged systematic theology of the pandemic. How do we imagine God in times like these? How do we see ourselves? The cry of dereliction on the cross becomes our lament. Trinitarian virtues like generosity and hospitality could become practices, which inform an ethic of civil responsibility. In the recent flourishing of Trinitarian thought, much has been made of alterity and communion. Analogously, this could easily be translated to human practices in a time of disruption. Bedford-Strohm (2018:xiv) talks about an 'ethic of self-limitation', which could be exceedingly relevant during a pandemic. The new COVIDself could be construed along the lines of anxiety and vulnerability, and also of embodiment, communion and especially of care of the other. It would be quite possible to design an ethic of the pandemic on the basis of Trinitarian resources, which cover a scope of human practices relative to the challenges of the crisis. This explicit lens for thinking God and self and practice together may arguably be the contribution of systematic theology to a hermeneutic of reading the Bible for orientation in a time of global insecurity.

\section{Conclusion}

To conclude, the purpose of this study was to offer a brief survey of some of the ways in which biblical scholars try to make sense of the COVID-19 pandemic, and to reflect on such attempts from bibliological and systematical perspectives. From a bibliological perspective, the following issues that played an important role in the studies that were discussed were noted: the richness of biblical traditions, the influence of social location on the interpretation of the pandemic in the light of the Bible, the importance of the emphasis on lament, the reluctance to interpret the pandemic as a punishment from God, the importance of interpreters' views of God and the emphasis on the way in which the 'new normal' should be approached. From a systematic perspective, the following issues were highlighted: the nature of doing theology as hermeneutical and the necessity to practise constructive theology; that the best way to theologise contemporary challenges is to relate them to the central symbol of the Divine; the importance of the over-arching narrative of the Bible and that sense-making should also have a performative function; the importance of an explicit Trinitarian identification of the Divine in making sense of the pandemic; the necessity of investigating the new self that may possibly emerge from the COVID-19 situation; and the importance of an ethics of civil responsibility. We trust that this study will aid other scholars in their future attempts to make sense of the pandemic from a Christian perspective.

\section{Acknowledgements}

This article is in honour of Prof. Stephan Joubert.

\section{Competing interests}

The authors declare that they have no financial or personal relationships that may have inappropriately influenced them in writing this article.

\section{Authors' contributions}

Both authors contributed equally to this article.

\section{Ethical considerations}

This article followed all ethical standards for research without direct contact with human or animal subjects. 


\section{Funding information}

This research received no specific grant from any funding agency in the public, commercial or not-for-profit sectors.

\section{Data availability}

Data sharing is not applicable to this article as no new data were created or analysed in this study.

\section{Disclaimer}

The views and opinions expressed in this article are those of the authors and do not necessarily reflect the official policy or position of any affiliated agency of the authors.

\section{References}

Bedford-Strohm, H., 2018, 'The Anthropocene as a challenge for a public theology', in C. Deane-Drummond, S. Bergmann \& M. Vogt (eds.), Religion in the Anthropocene, pp. xi-xiv, Wipf and Stock, Eugene, OR.

Bentzen, J., 2020, 'In crisis, we pray: Religiosity and the COVID-19 pandemic', CEPR discussion paper No. DP14824, viewed 15 December 2020, from https://ssrn. com/abstract $=3615587$.

Brueggemann, W., 2020, Virus as a summons to faith: Biblical reflections in a time of loss, grief and anxiety, Cascade Books, Eugene, OR.

Chamburuka, M. \& Gusha, I.S., 2020, 'An exegesis of the parable of the Good Samaritan (Lk 10:25-35) and its relevance to the challenges caused by COVID-19', HTS Teologiese Studies/Theological Studies 76(1), a6096. https://doi.org/10.4102/ hts.v76i1.6096

Duquoc, C., 1992, “"Who is God?" becomes "Where is God?" The shift in a question” in C. Duquoc \& C. Floristán (eds.), Where is God? A cry of human distress, pp. 1-10, SCM, London.
Goldingay, J. \& Scott Goldingay, K., 2020, 'Thinking with the Old Testament about the pandemic', Theology 123(3), 191-197. https://doi.org/10.1177/0040571X20920527

Gregersen, N.H. \& Henriksen, J.-O., 2017, 'Endangered selves and societies: Theologies of tragedy and disaster', Dialog 56(4), 331-334. https://doi.org/10.1111/dial.12352

Hadot, P., 1995, Philosophy as a way of life, Blackwell, Oxford.

Henriksen, J.-O., 2019, Christianity as distinct practices: A complicated relationship, T \& T Clark, London.

Hollinger, D.P., 2002, Choosing the good: Christian ethics in a complex world, Baker, Grand Rapids, MI.

Isiko, A.P., 2020, 'Religious construction of disease: An exploratory appraisal of religious responses to the COVID-19 pandemic in Uganda', Journal of African Studies and Development 12(3), 77-96. https://doi.org/10.5897/JASD2020.0573

Lampe, P., 2020, 'Health and politics in the COVID-19 crisis from a New Testament hermeneutical perspective', Acta Theologica 40(2), 116-124. https://doi. org/10.18820/23099089/actat.v40i2.07

Pradeu, T., Kostyrka, G. \& Dupré, J., 2016, 'Understanding viruses: Philosophical investigations', Studies in History and Philosophy of Biological and Biomedical investigations, Studies in History and Philosophy of Biological
Sciences 59, 57-63. https://doi.org/10.1016/j.shpsc.2016.02.008

Smit, D., 2009, 'The Trinity in the reformed tradition', Journal of Reformed Theology 3(1), 57-76. https://doi.org/10.1163/156973109X403723

Steyn, M. \& Wepener, C., (in press), 'Pandemic, preaching and progression: A grounded theory exploration and homiletical praxis theory'.

Steyn, M., Wepener, C. \& Pieterse, H., 2020, 'Preaching during the COVID-19 pandemic in South Africa: A grounded theoretical exploration', International Journal of Homiletics 4, 1-20.

Thomas, G, 2020 'Theology in the shadow of the corona crisis', Cursor-Zeitschrift für Explorative Theologie, pp. 2-15. https://doi.org/10.21428/fb61f6aa.7fb2004b

Vermeer, P. \& Kregting, J., 2020, 'Religion and the transmission of COVID-19 in the Netherlands', Religions 11(8), 393. https://doi.org/10.3390/rel11080393

Webster, J., 2007, 'Systematic theology', in J. Webster, K. Tanner \& I. Torrance (eds.), The Oxford handbook of systematic theology, pp. 1-15, Oxford University Press, Oxford.

Williams, R., 2020, Candles in the dark: Faith, hope and love in a time of pandemic, SPCK, London.

Wright, N.T., 2020, God and the pandemic: A Christian reflection on the coronavirus and its aftermath, Zondervan, Grand Rapids, MI.

Zhang, Y., 2020, 'Reading the book of job in the pandemic', Journal of Biblical Literature 139(3), 607-612. https://doi.org/10.1353/jbl.2020.0033 